\title{
Remarkable new beetle from central Italy
}

THE coleopterous fauna of Europe is undoubtedly better known than that of any comparable continental area in the world. By this time, to discover even a species new to science is a notable event in the life of a beetle collector; the discovery of a genuinely new genus in western Europe is something very few can hope to achieve. The finder of a new species representing a new taxon at higher than the generic level is almost unique in the last half century.

The fact that this has been achieved by Signor Roberto Pace of Verona, is not purely a matter of good fortune; he has been actively exploring a type of habitat which beetle collectors, except for a few in France, have largely neglected-the deeper layers of the soil. For the lack of an established English term for beetles of this type, we may adopt the French endogées. Endogean beetles have a good deal in common with cavernicolous ones-also studied mainly in France-and like them are scarcely represented in the British fauna. Endogées are usually small, eyeless, wingless, and more or less depigmented; from the obscurity of their habitat, very little is known about their foods or life cycles.

The insect discovered near Lazio in Central Italy by Pace (Boll. Mus. civ. St. nat. Verona, II, 445; 1975) represents not merely a new taxon of at least tribal level, but also a family and suborder hitherto unknown in the modern European fauna-and within the family and suborder represents a new and quite unexpected adaptive type. The suborder Archostemata, to which Crowsoniella relicta Pace belongs, is today a very small relict group, to which the oldest known fossils of Coleoptera (of Permian age, see Ponomarenko, (The Historical Development of Archostematan Beetles, Moscow, 1969)) have been attributed. Fossils of Archostemata are more or less numerous in "insect beds" throughout the Mesozoic era, but become much rarer in Tertiary deposits, more or less parallel to egg-laying mammals or Dipnoan lung-fishes.

Recent Archostemata are now placed in four small families (Crow-

746 ; 1976) examined for $e$ antigen and antibody, serum samples from twentythree pregnant women who were asymptomatic carriers of hepatitis B surface antigen. Ten mothers with $e$ antigen and seven with $e$ antibody were identified. Their babies were tested at intervals for over a year after birth. All ten babies born to mothers with the $c$ antigen acquired the surface antigen

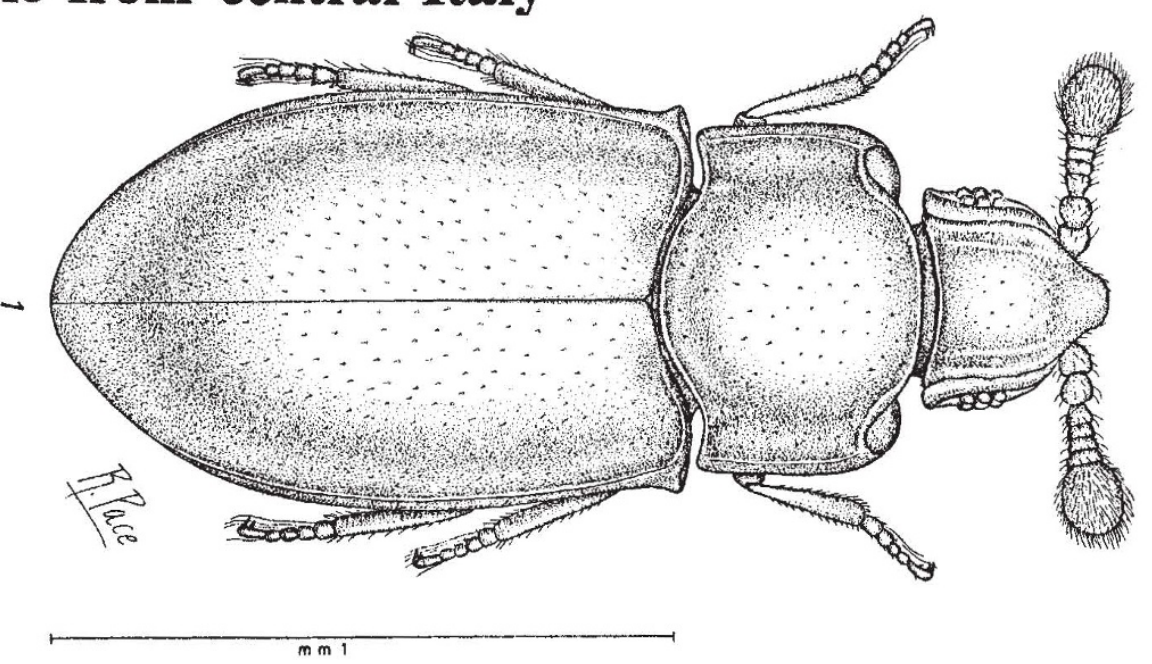

son, Boll. Mus. civ. St. nat. Verona, II, 459; 1975): Ommadidae with one genus and two species in Australia; Tetraphaleridae with two species of Tetraphalerus in extra-tropical South America plus Crowsoniella in Italy; Cupedidae with four genera and about twenty species distributed through the main continental areas except for Europe and New Zealand; and Micromalthidae with a species in North America and a possibly distinct one in South Africa (Pringle, Trans. $R$. ent. Soc. Lond., 87, 271; 1938). The larvae are definitely known to be woodborers in Micromalthus and a number of species of Cupes in America, Japan and Australia, and it is believed that this habit is general in the suborder. Except for Micromalthus and Crowsoniella, modern Archostemata are moderate-sized beetles with a body length rarely less than $7 \mathrm{~mm}$, with well-developed wings, and active flight has been noted in several species.

Apart from Crowsoniella, the only record of subterranean habits in the group is for Micromalthus, found breeding in timbers of more or less deep mines in South Africa (Pringle, op. cit). However, species of Tetraphalerus have been collected in Argentina (Monros and Monros, $A n$. Soc. cient. Argentina, 154, 19; 1952) in areas of bushy vegetation with no large trees, which would seem to be unlikely to furnish the fungusattacked dead trunks and logs which

which persisted throughout the period of observation, and interestingly enough all ten elder siblings of these newborn infants were also found to be asymptomatic carriers. In marked contrast, all seven babies born to mothers with $e$ antibody escaped infection with hepatitis $B$ virus and none of their three elder siblings were surface antigen carriers. It was concluded that the are the usual breeding grounds of Cupes species; it seems quite possible that Tetraphalerus breeds in dead roots underground. If so, the habits of Crowsoniella might appear as a natural development from those of Tetraphalerus.

The antiquity of the Tetraphalerus line is indicated by well-preserved fossils, apparently close to the recent genus, in Jurassic deposits of the USSR (Ponomarenko, op. cit.), and the Tertiary occurrence of the type in Europe is shown by the fossil Tetraphalerites oligocenius (Crowson, Ann. Mag. nat. Hist, (B) 5, 147; 1962) from the Bembridge limestone of the Isle of Wight. The Crowsoniella line may well have evolved its flightless and subterranean adults in the Mediterranean region during the Tertiary era. In having antennal grooves above rather than below the eyes, Crowsoniella differs from Tetraphalerus but may resemble some of the Mesozoic fossils described by Ponomarenko-the separation of the two lines may even be of Jurassic origin. Unfortunately the head is not preserved in the fossil Tetraphalerites.

Crowsoniella is surely one of the most ancient elements in the hypogean fauna of Europe; the possibility remains that related types will eventually be discovered elsewhere, e.g. in the Balkan peninsula, or even the Crimea or the Caucasus, if and when systematic search for hypogean forms is undertaken in those areas. $e$ antigen may be used as an indicator of transmission of hepatitis $\mathbf{B}$ virus from carrier mothers to their children. Interesting results were also obtained by Grady and colleagues (Lancet, ii, 492: 1976) during a survey of medical personnel accidentally inoculated with blood containing hepatitis B surface antigen. Hepatitis B infection or a surface antibody response occurred in 